\title{
Epidemiology of bacterial meningitis
}

\author{
H M Fortnum, A C Davis
}

\begin{abstract}
This 10 year retrospective study of all causes of bacterial meningitis for children resident in Nottingham District Health Authority area reports an annual incidence rate per 100000 children aged 0-16 years of 16.0 (95\% confidence interval 14-0 to 18.1). There was a steady increase in incidence from $9.6 / 100000$ in 1980 to $24 \cdot 3 / 100000$ in 1989 . This was mainly due to an increase in the incidence of meningococcal infections in the age group 1 month to 5 years.

Incidence rates varied with age being: $37 \cdot 2$ I $100000(25.9$ to 53.5$)$ for 0-28 days of age, $115.5 / 100000(93.9$ to 141.9$)$ for 1-11 months of age, $28.5 / 100000(23.1$ to 35.3$)$ for $12-59$ months of age, and $2.8 / 100000(1.9$ to 4.1$)$ for 5-16 years of age.

Overall annual mortality incidence per 100000 was $1.8(1.2$ to $2 \cdot 8)$. For the different age groups this was: $10 \cdot 1$ (4.8 to $21 \cdot 1)$ for $0-28$ days, $11.5(6.0$ to 22.2$)$ for 1-11 months, 1.0 $(0.3$ to 3.1$)$ for $12-59$ months, and $0.4(0.1$ to $1 \cdot 2)$ for 5-16 years of age. There were interactions between the type of meningitis and the year of the infection on the mortality rate. Mortality decreased in those with infections caused by bacteria other than Neisseria meningitidis and Haemophilus influenzae.

(Arch Dis Child 1993; 68: 763-767)
\end{abstract}

Bacterial meningitis remains one of the most devastating illnesses that child and family can experience. Despite improvements in treatment in the past $40-50$ years, antibiotics in the 1940s and $1950 \mathrm{~s}^{1}$ and, more recently, steroid treatment, ${ }^{2-4}$ mortality remains high: between 3 and $10 \%$ of all affected children after the neonatal period $^{5-8}$ and between 25 and $50 \%$ of neonates. 57910 For the survivors, sequelae can include hydrocephalus, mental and/or physical handicap, disturbance of motor function, convulsions, sensorineural hearing impairment, ataxia, and emotional disturbance. ${ }^{46811-15}$

There is evidence that the incidence of bacterial meningitis in children has been increasing,,$^{11} 1617$ that mortality may be declining, ${ }^{16}{ }^{17}$ and that the profile of different causative organisms is changing in some locations. ${ }^{17}$ Consequently more of the seriously ill children may be surviving with long term sequelae.

The recent literature suggests that $6-12 \%$ of meningitis survivors have some form of hearing impairment $^{18}$ and that most paediatricians are aware of the need for auditory assessment after meningitis. ${ }^{19}$ If every survivor had formal auditory assessment, the major determinants of the audiological resources demanded by bacterial meningitis would be its incidence, mortality, and morbidity.

Much of the published data on the epidemiology of bacterial meningitis in children comes from the USA ${ }^{1520-23}$ or northern Europe. ${ }^{8162425}$ Data for the UK have been reported 57101114172627 but often the epidemiology of only one causative organism $^{11} 142627$ or one particular age group ${ }^{710}$ has been studied. Data based on notification figures are unreliable. The undernotification of meningitis is well recognised, ${ }^{1128}$ and differences in the rate of notification between health districts mean that calculations of national incidence cannot be made without gross assumptions.

This paper provides incidence and mortality data for 1980-9 for all causes of bacterial meningitis in children (0-16 years) resident in Nottingham District Health Authority area. It also reports data for the larger group of children treated in the two teaching hospitals serving the district health authority thus providing further information on some of the resource implications of this illness.

\section{Methods}

This retrospective study analysed all cases of bacterial meningitis occurring in children aged less than 16 years who were admitted to one of the two units providing paediatric services to Nottingham District Health Authority (1989 population 615000 ) from 1 January 1980 to 31 December 1989.

Children were initially identified from a register, held by one of the local consultant microbiologists, of all cases of bacterial meningitis confirmed by the microbiology departments of the two hospitals. To include cases with no examination of the cerebrospinal fluid (CSF), additions to the study group were sought from the records of official notifications of meningitis held by the local officers for communicable diseases, and the records of other researchers conducting a national study of meningitis in the first year of life.?

Details of the child, the clinical course of the illness, the outcome, and any residual problems were abstracted from medical casenotes and cases were included in the study if they satisfied the criteria shown in table 1.

Over the period of study the two hospitals routinely accepted cases from the three sur-

Table 1 Inclusion criteria

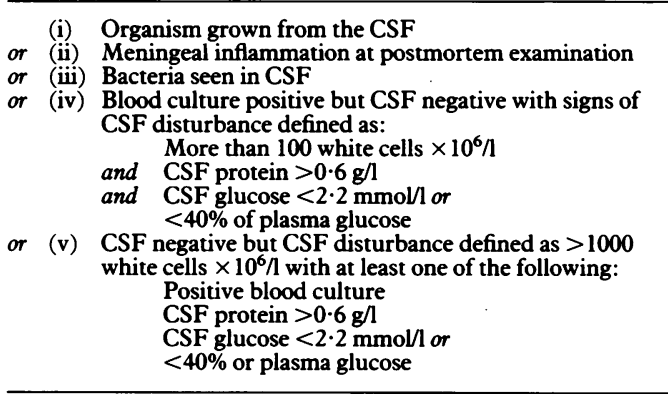

Research, Nottingham University, Nottingham NG7 2RD

H M Fortnum

Correspondence and requests for reprints to: Dr Fortnum.

Accepted 7 February 1993 
Table 2 Incidence of bacterial meningitis per 100000 children in Nottingham District Health Authority: $(A)$ for children aged 0 to 16 years for the years 1980 to 1989 and $(B)$ for four age groups over the 10 year period

\begin{tabular}{|c|c|c|}
\hline & No & Incidence $(95 \% C I)$ \\
\hline \multicolumn{3}{|l|}{ (A) Age 0-16 (years): } \\
\hline $\begin{array}{l}1980 \\
1981\end{array}$ & 14 & $9.2(5.4$ to $15 \cdot 5)$ \\
\hline 1982 & 10 & $6.7(3.6$ to 12.5$)$ \\
\hline 1983 & 26 & $17 \cdot 8(12 \cdot 1$ to $26 \cdot 1)$ \\
\hline 1984 & 19 & $13 \cdot 2(8 \cdot 4$ to $20 \cdot 6)$ \\
\hline 1985 & 23 & $16 \cdot 0(10 \cdot 6$ to $24 \cdot 1)$ \\
\hline 1986 & 27 & $19 \cdot 0(13 \cdot 1$ to $27 \cdot 8)$ \\
\hline 1987 & 28 & $20.0(13.8$ to 28.9$)$ \\
\hline 1988 & 36 & $25 \cdot 8(18.6$ to $35 \cdot 7)$ \\
\hline 1989 & 34 & $24 \cdot 3(17 \cdot 4$ to $34 \cdot 0)$ \\
\hline \multicolumn{2}{|l|}{ (B) Years 1980-9 (age group): } & \\
\hline $\begin{array}{l}0-28 \text { days } \\
1-11 \text { months }\end{array}$ & 29 & $\begin{array}{c}37.2(25.9 \text { to } 53.5) \\
115.5(93.9 \text { to } 141.9)\end{array}$ \\
\hline $\begin{array}{l}\text { 1-11 months } \\
12-59 \text { months }\end{array}$ & $\begin{array}{l}90 \\
85\end{array}$ & $28 \cdot 5(23 \cdot 1$ to $35 \cdot 3)$ \\
\hline $5-16$ years & 28 & $2.8(1.9$ to 4.1$)$ \\
\hline
\end{tabular}

rounding district health authorities. Children resident in Nottingham District Health Authority area were unlikely to have been treated in another hospital unless they became ill when away from home. Incidence rates for Nottingham children in four age groups $(<28$ days, 1-11 months, 12-59 months, 5-16 years) were therefore calculated using cases from the study as the numerator. For neonates, the denominator used was the annual number of live births and for the other age groups, the mid-year estimate made available by the Office of Population Censuses and Surveys.

Analyses were performed using the P-STAT ${ }^{30}$ and $\mathrm{GLIM}^{31}$ statistical packages.
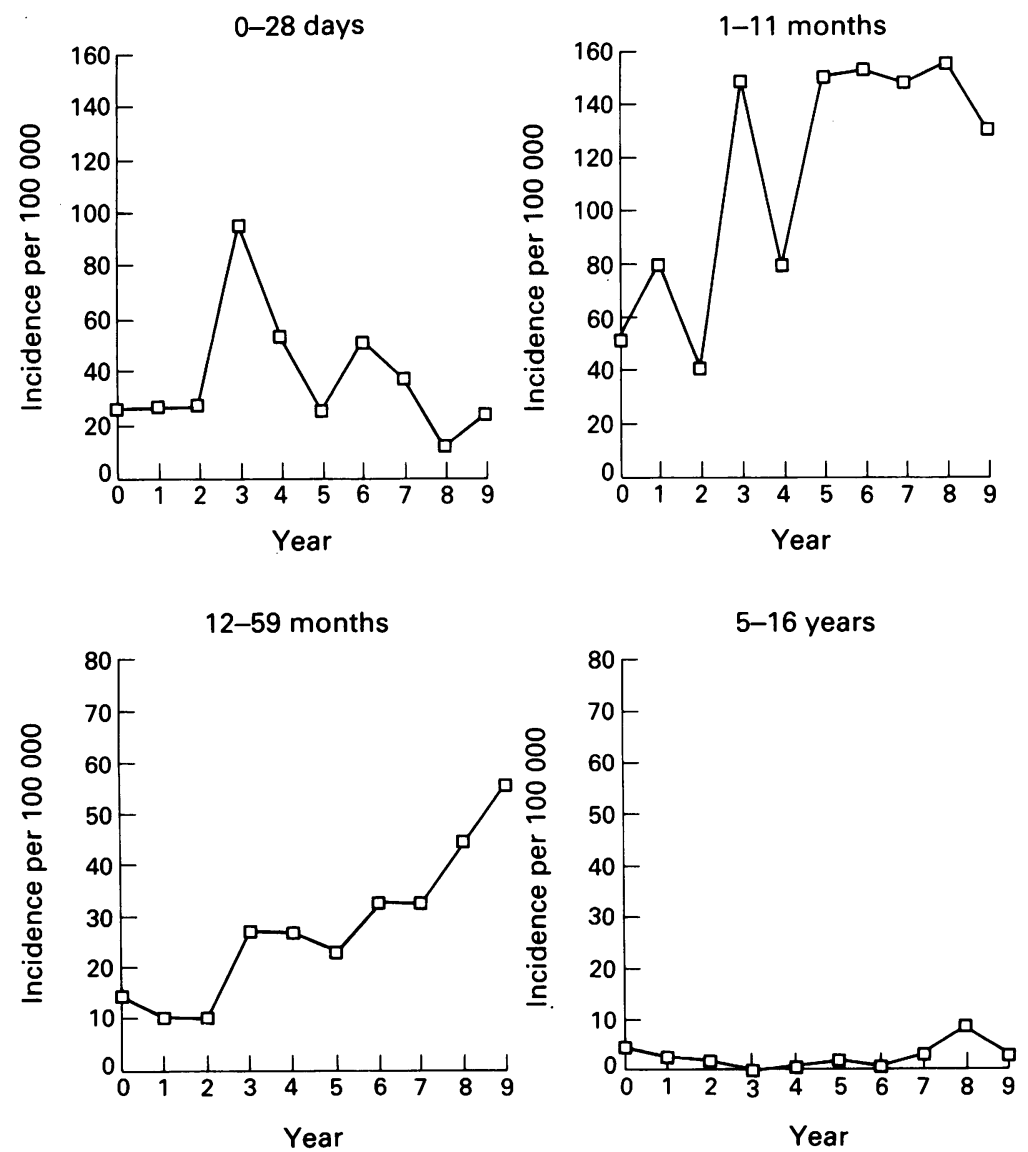

Annual incidence per 100000 of bacterial meningitis in Nottingham District Health Authority area for the period 1980 (0) for four age groups. (Note: $y$ axes differ between the four graphs.)

\section{Results}

CASES

A total of 300 children having 301 episodes of bacteral meningitis were identified: 283 from the laboratory records, 102 from the official notifications ( 14 of whom were not on the laboratory list), 38 from other researchers (three of whom were unknown to the laboratory or the official notifications), and one case from a report in a local newspaper that had not been identified from any of the other sources. The casenotes for all but two children were eventually traced. Information on one of these was gathered from community sources and audiology clinics but little information has been traced for the other child. Seven of the 301 cases were included even though they did not completely meet the criteria in table 1. Four of these cases had no lumbar puncture but had positive blood culture together with other clinical signs of meningitis. The other three had negative CSF culture, with or without positive blood culture, plus at least one but not all three CSF changes shown in table 1 (iv). All seven cases were considered clinically to have meningitis. Five were resident in the Nottingham District Health Authority area.

\section{INCIDENCE}

Children resident in the district health authority area were involved in $232(77 \cdot 1 \%)$ of the episodes. Incidence rates overall by year and age group are shown in table 2 . The figure illustrates the changing incidence for each of the four age groups. The increase in incidence overall shows an approximately linear trend increasing by about a quarter every two years over the decade. This is accounted for largely by the age group from 12 to 59 months. The current incidence in this group represents an approximately fourfold increase on that of the early 1980s. The incidence was analysed using a logistic model. The factors of age group (0-28 days, 1-11 months, 12-59 months, 5-16 years), organism (Neisseria meningitidis, Haemophilus influenzae, other bacteria), and year (two year bands) significantly affected incidence; sex did not. However, there were several interactions involving year, so each organism was assessed separately for a secular trend. For $N$ meningitidis, $H$ influenzae; and other bacteria the linear trends in incidence were respectively an increase of $24 \%$ (95\% confidence interval (CI) 13 to $37 \%$ ), $12 \%$ ( 2 to $22 \%$ ), and $11 \%$ (1 to $23 \%$ ) per annum. There were no significant higher order trends. For each type of bacterial meningitis and individual age group statistically significant linear increases in incidence were seen for three combinations: (i) $N$ meningitidis in the $1-11$ month age group, $20 \%$ ( 2 to $43 \%$ ) increase per annum, (ii) $N$ meningitidis in the $12-59$ month age group, $32 \%$ (12 to $57 \%$ ) increase per annum, and (iii) other bacteria in the $12-59$ month age group, $63 \%$ (7 to $175 \%$ ) increase per annum. The incidence per 100000 of $N$ meningitidis in the 12-59 month age group increased sixfold from 3.6 in $1980-1$ to 23.6 in 1988-9, while the incidence of $H$ influenzae for the same age group only doubled from 9.0 in $1980-1$ to $17 \cdot 3$ in 1988-9.

Estimates of the cumulative risk of acquiring 
Table 3 Cumulative risk, expressed as number of children per case, of acquiring bacterial meningitis, meningococcal meningitis, $\mathrm{H}$ influenzae meningitis and meningitis caused by other bacteria, for birth cohorts resident in Nottingham District Health Authority area $(95 \% \mathrm{CI})$

\begin{tabular}{|c|c|c|c|c|}
\hline & All bacteria & $\mathrm{N}$ meningitidis & $\mathbf{H}$ influenzae & Other bacteria \\
\hline $\begin{array}{l}\text { Before third birthday: birth cohort 1980-6 } \\
\text { No of cases } \\
\text { Before second birthday: birth cohort 1980-7 } \\
\text { No of cases } \\
\text { Before first birthday: birth cohort 1980-8 } \\
\text { No of cases } \\
\text { Before 31 December 1989: birth cohort 1980-9 } \\
\text { No of cases }\end{array}$ & $\begin{array}{l}415(494 \text { to } 349) \\
128 \\
474(564 \text { to } 399) \\
129 \\
626(754 \text { to } 520) \\
111 \\
400(460 \text { to } 347) \\
195\end{array}$ & $\begin{array}{l}1714 \text { (2438 to } 1206) \\
31 \\
2354(3458 \text { to } 1603) \\
26 \\
2675(3928 \text { to } 1821) \\
26 \\
1299(1673 \text { to } 1009) \\
60\end{array}$ & $\begin{array}{l}1042 \text { (1371 to } 792) \\
51 \\
1200(1579 \text { to } 912) \\
51 \\
2045(2862 \text { to } 1462) \\
34 \\
1082(1364 \text { to } 859) \\
72\end{array}$ & $\begin{array}{l}1155(1542 \text { to } 866) \\
46 \\
1177 \text { (1545 to } 897) \\
52 \\
1363(1794 \text { to } 1036) \\
51 \\
1237(1583 \text { to } 967) \\
63\end{array}$ \\
\hline
\end{tabular}

infection can be made for certain birth cohorts. Table 3 shows a three year risk (1980-6 birth cohort) for all types of bacterial meningitis of one in 415. The risk of $N$ meningitidis meningitis was one in 1700 , while $H$ influenzae meningitis and all other types had approximately equal risks of about one in 1100 . The risk to a child born in the period 1980 to 1989 to suffering an episode of bacterial meningitis by 31 December 1989 was one in 400. This statistic represents the cumulative risk for childhood bacterial meningitis for the decade in a useful way but the children included had not, of course, lived through an equal number of risk years.

\section{MORTALITY}

Table 4 shows the annual mortality incidence per 100000 from bacterial meningitis for 1980 to 1989 for four age groups between 0 and 16 years

Table 4 Annual mortality incidence from bacterial meningitis in the period 1980 to 1989 for children aged 0 to 16 years in the Nottingham District Health Authority area

\begin{tabular}{lll}
\hline Age group & $\begin{array}{l}\text { Morality incidence } \\
\text { per } 100000\end{array}$ & $95 \% C I$ \\
\hline $0-28$ days & $10 \cdot 1$ & $4 \cdot 8$ to $21 \cdot 1$ \\
$1-11$ months & 11.5 & $6 \cdot 0$ to $22 \cdot 2$ \\
$12-59$ months & $1 \cdot 0$ & 0.3 to $3 \cdot 1$ \\
$5-16$ years & $0 \cdot 4$ & 0.1 to $1 \cdot 2$ \\
Overall & $1 \cdot 8$ & $1 \cdot 2$ to $2 \cdot 8$ \\
\hline
\end{tabular}

resident in the Nottingham District Health Authority area. The highest rates, 5-6 times the overall, were seen in children under 12 months of age.

\section{RESOURCE IMPLICATIONS}

Table 5 presents the data on age, organism, and mortality for the total group of 301 children. The two most prevalent organisms were $N$ meningitidis and $H$ influenzae accounting for two thirds of the cases and distributed across all ages except neonates (one case only). Escherichia coli and group B haemolytic streptococcal infections occurred only in those under 3 months of age with one exception, a 10 month old child with $E$ coli who died. Organisms in the 'other' category are listed at the bottom of the table. These accounted for $6 \%$ of the total and were spread across all the age groups.

The overall case fatality was $11.6 \%(95 \% \mathrm{CI}$ 8.5 to $15 \cdot 8 \%$ ). In addition three children died later as a result of complications of the illness. If these children are included the overall case fatality rate becomes $12 \cdot 6 \%$. The highest mortality rate was seen in the neonatal age group.

Children with meningitis caused by $N$ meningitidis and $H$ influenzae had the lowest mortality rates over the decade of $5 \%$ and $6.1 \%$ respectively. All other causes have rates of $20 \%$ or more and in the case of $E$ coli infections, nearly half the children died. For $N$ meningitidis and

Table 5 Distribution of, and mortality within, 301 cases of bacterial meningitis in children aged less than 16 years treated in Nottingham hospitals from 1 fanuary 1980 to 31 December 1989 within six age groups and six categories of infecting organism

\begin{tabular}{|c|c|c|c|c|c|c|c|c|}
\hline & $\mathrm{N}$ meningitidis & $\mathbf{H}$ influenzae & $\begin{array}{l}\text { Streptococcus } \\
\text { pneumoniae }\end{array}$ & E coli & $\begin{array}{l}\text { Group B } \\
\text { haemolytic } \\
\text { streptococcus }\end{array}$ & $\begin{array}{l}\text { Other } \\
\text { bacteria }\end{array}$ & $\begin{array}{l}\text { Not } \\
\text { known }\end{array}$ & $\begin{array}{l}\text { Total No (died) } \\
\% \text { Total } \\
\% \text { Mortality } \\
(95 \% \text { CI })\end{array}$ \\
\hline $\begin{array}{l}\text { 0-28 days } \\
\text { No (died) } \\
\% \text { Type } \\
\% \text { Age } \\
\text { 1-11 months }\end{array}$ & $\begin{array}{l}1(0) \\
1 \cdot 0 \\
2 \cdot 6\end{array}$ & $\begin{array}{l}0(0) \\
0 \\
0\end{array}$ & $\begin{array}{l}2(1) \\
5 \cdot 7 \\
5 \cdot 1\end{array}$ & $\begin{array}{l}13(5) \\
81 \cdot 3 \\
33 \cdot 3\end{array}$ & $\begin{array}{l}13(2) \\
56 \cdot 5 \\
33 \cdot 3\end{array}$ & $\begin{array}{l}8(2) \\
40 \cdot 0 \\
20 \cdot 5\end{array}$ & $\begin{array}{c}2(0) \\
28 \cdot 6 \\
5 \cdot 1\end{array}$ & $\begin{array}{l}39(10) \\
13 \cdot 0 \\
25 \cdot 6(14 \cdot 4 \text { to } 41 \cdot 4)\end{array}$ \\
\hline $\begin{array}{l}\text { No (died) } \\
\% \text { Type } \\
\% \text { Age } \\
\text { 12-59 months }\end{array}$ & $\begin{array}{l}34(2) \\
33 \cdot 7 \\
27 \cdot 6\end{array}$ & $\begin{array}{l}50(4) \\
50 \cdot 5 \\
40 \cdot 7\end{array}$ & $\begin{array}{l}19(4) \\
54 \cdot 3 \\
15 \cdot 4\end{array}$ & $\begin{array}{c}3(2) \\
18 \cdot 7 \\
2 \cdot 4\end{array}$ & $\begin{array}{l}10(3) \\
43 \cdot 5 \\
8 \cdot 1\end{array}$ & $\begin{array}{c}6(1) \\
30 \cdot 0 \\
4 \cdot 9\end{array}$ & $\begin{array}{c}1(0) \\
14 \cdot 3 \\
0.8\end{array}$ & $\begin{array}{l}123(16) \\
40 \cdot 9 \\
13 \cdot 0(8 \cdot 1 \text { to } 20 \cdot 2)\end{array}$ \\
\hline $\begin{array}{l}\text { No (died) } \\
\% \text { Type } \\
\% \text { Age } \\
\text { 5-16 years }\end{array}$ & $\begin{array}{l}42(2) \\
41 \cdot 6 \\
40 \cdot 4\end{array}$ & $\begin{array}{l}49(2) \\
49 \cdot 5 \\
47 \cdot 1\end{array}$ & $\begin{array}{l}9(1) \\
25 \cdot 7 \\
8 \cdot 7\end{array}$ & $\begin{array}{l}0(0) \\
0 \\
0\end{array}$ & $\begin{array}{l}0(0) \\
0 \\
0\end{array}$ & $\begin{array}{l}1(0) \\
5 \cdot 0 \\
1 \cdot 0\end{array}$ & $\begin{array}{c}3(0) \\
42.9 \\
2.9\end{array}$ & $\begin{array}{l}104(5) \\
34 \cdot 6 \\
4 \cdot 8(2 \cdot 1 \text { to } 11 \cdot 0)\end{array}$ \\
\hline $\begin{array}{l}\text { No (died) } \\
\text { \% Type } \\
\text { \% Age }\end{array}$ & $\begin{array}{l}24(1) \\
23 \cdot 8 \\
68 \cdot 6\end{array}$ & $\begin{array}{l}0(0) \\
0 \\
0\end{array}$ & $\begin{array}{l}5(1) \\
14 \cdot 3 \\
14 \cdot 3\end{array}$ & $\begin{array}{l}0(0) \\
0 \\
0\end{array}$ & $\begin{array}{l}0(0) \\
0 \\
0\end{array}$ & $\begin{array}{l}5(2) \\
25 \cdot 0 \\
14 \cdot 3\end{array}$ & $\begin{array}{c}1(0) \\
14 \cdot 3 \\
2 \cdot 9\end{array}$ & $\begin{array}{l}35(4) \\
11 \cdot 6 \\
11 \cdot 4(4 \cdot 4 \text { to } 26 \cdot 8)\end{array}$ \\
\hline $\begin{array}{l}\text { Total } \\
\text { No (died) } \\
\% \text { Type } \\
\% \text { Mortality } \\
\text { (95\% CI) }\end{array}$ & $\begin{array}{l}101(5) \\
33 \cdot 6 \\
5 \cdot 0 \\
(2 \cdot 1 \text { to } 11 \cdot 4)\end{array}$ & $\begin{array}{l}99(6) \\
32 \cdot 9 \\
6 \cdot 1 \\
(2 \cdot 7 \text { to } 12 \cdot 8)\end{array}$ & $\begin{array}{l}35(7) \\
11.6 \\
20 \cdot 0 \\
\quad(9 \cdot 8 \text { to } 36 \cdot 4)\end{array}$ & $\begin{array}{l}16(7) \\
5 \cdot 3 \\
43 \cdot 8 \\
(22 \cdot 5 \text { to } 67 \cdot 6)\end{array}$ & $\begin{array}{l}23(5) \\
7 \cdot 6 \\
21 \cdot 7 \\
(9 \cdot 3 \text { to } 42 \cdot 8)\end{array}$ & $\begin{array}{l}20(5) \\
6 \cdot 6 \\
25 \cdot 0 \\
(10 \cdot 8 \text { to } 47 \cdot 8)\end{array}$ & $\begin{array}{l}7(0) \\
2 \cdot 3 \\
0 \\
(0 \text { to } 57 \cdot 7)\end{array}$ & $\begin{array}{l}301(35) \\
100.0 \\
11.6(8.5 \text { to } 15.8)\end{array}$ \\
\hline
\end{tabular}

^Listeria monocytogenes 2 (0), Salmonella bredeney 2 (0), Staphylococcus aureus 3 (0), Pseudomonas aeruginosa 2 (2), bacteroides 3 (1), Salmonella enteritidis 1 (0), Mycobacterium tuberculosis 2 (0), Streptococcus viridans 1 (1), Citrobacter fruendii 1 (0), Enterobacter agglomerans 1 (0), Streptococcus faecaelis 1 (0), Serratia marcescens 1 (1). 
Table 6 Odds ratios $(95 \%$ CI) for factors that significantly affect mortality rate for two subgroups of infecting organism and two subgroups of the study population

\begin{tabular}{|c|c|c|c|c|}
\hline \multirow{2}{*}{$\begin{array}{l}\text { Factor } \\
\text { CSF glucose concentration } \\
N \text { meningitidis and } H \text { influenzae } \\
\text { Other bacteria }\end{array}$} & \multicolumn{2}{|l|}{ Total group $(n=298)$} & \multicolumn{2}{|c|}{$\begin{array}{l}\text { Nottingham District Health Authority area } \\
(n=229)\end{array}$} \\
\hline & $\begin{array}{l}<1 \mathrm{mmoll} / \\
1 \cdot 08(0 \cdot 16 \text { to } 7 \cdot 2) \\
12 \cdot 51(1 \cdot 48 \text { to } 105 \cdot 66)\end{array}$ & $\begin{array}{l}\text { Missing } \\
7.93(1.52 \text { to } 41.35) \\
25.9(2.9 \text { to } 231.8)\end{array}$ & $\begin{array}{l}<1 \mathrm{mmol} / \mathrm{l} \\
0 \cdot 89(0 \cdot 05 \text { to } 15 \cdot 5) \\
7 \cdot 7(0 \cdot 84 \text { to } 71 \cdot 5)\end{array}$ & $\begin{array}{l}\text { Missing } \\
18 \cdot 8(1.6 \text { to } 219.9) \\
21.2(1.9 \text { to } 241.5)\end{array}$ \\
\hline $\begin{array}{l}\text { Presence of other problems } \\
N \text { meningitidis and } H \text { influenzae } \\
\text { Other bacteria }\end{array}$ & \multicolumn{2}{|c|}{$\begin{array}{l}7.92(1.86 \text { to } 33 \cdot 8) \\
-\end{array}$} & \multicolumn{2}{|c|}{$21 \cdot 0(2 \cdot 6$ to $166 \cdot 1)$} \\
\hline $\begin{array}{l}\text { Year (two-year bands, linear trend) } \\
N \text { meningitidis and } H \text { influenzae } \\
\text { Other bacteria }\end{array}$ & \multicolumn{2}{|c|}{$\begin{array}{l}2.46(1.11 \text { to } 5.45) \\
0.51(0.33 \text { to } 0.8)\end{array}$} & \multicolumn{2}{|c|}{$\overline{0.44}(0.24$ to 0.82$)$} \\
\hline
\end{tabular}

^Temporary or permanent complications such as hydrocephalus, neurological damage, respiratory or circulatory problems

-Represents where factors did not reach $5 \%$ level for inclusion in the model for a particular subgroup.

$H$ influenzae together there was a linear increasing trend in case mortality over the decade from $0 \%$ in $1980-1$ to $8 \%$ in $1988-9\left(\chi^{2}=7 \cdot 2, \mathrm{df}=1\right.$, $\mathrm{p}<0.01)$. For all other types of bacterial meningitis there was a steady decrease from $61 \%$ in $1980-1$ to $9 \%$ in $1988-9\left(\chi^{2}=10 \cdot 5, \mathrm{df}=1\right.$, $\mathrm{p}<0.005)$. Looking at only the children living in the Nottingham District Health Authority area the same trend is seen for meningitis caused by other bacteria, but there were only seven deaths for $N$ meningitidis/H influenzae meningitis, which was insufficient to document any trend in mortality.

\section{PREDICTORS OF MORTALITY}

An initial analysis of the data using a logistic model of mortality with GLIM $^{31}$ indicated a strong interaction of year trend with type of infecting organism (as might be expected from the figure). For further analysis the data were grouped into (1) $N$ meningitidis/H influenzae and (2) other bacteria and risk factors were treated as significant if the decrease in deviance $\left(\chi^{2}\right)$ for their inclusion was significant in the presence of the other significant factors. The odds ratios presented in table 6 are thus adjusted for the inclusion of each significant risk factor. The three factors shown in table 6 that were significant in at least one subgroup analysis were CSF glucose concentration, the presence of other problems, and the linear trend with year of meningitis. The CSF glucose concentration had three levels $(\geqslant 1 \mathrm{mmol} / 1,<1 \mathrm{mmol} / 1$, and missing data) and was significant in all four subgroups. This was predominantly due to the contribution of the 'missing data' level, but as can be seen from the odds ratios in table 6 , there was some evidence of raised mortality for other organisms at the $<1 \mathrm{mmol} / \mathrm{l}$ level. For the $N$ meningitidis and $H$ influenzae grouping this level of the factor was not significant.

No raised risk was found for age group, sex, high concentrations of CSF protein, raised CSF white cell count, time from onset of symptoms to admission, presence of a rash on admission, antibiotic treatment before admission, or whether or not the child transferred from another hospital.

\section{MORBIDITY}

Twenty five of the 266 survivors $(9 \cdot 4 \%, 95 \%$ CI 6.4 to $13 \cdot 5 \%$ ) suffered permanent neurological or psychological problems, ranging from relatively minor behavioural problems to major disturbances of motor function. Fifteen of these 25 children (5.6\% survivors, $95 \%$ CI 3.4 to $9 \cdot 1 \%$ ) suffered a permanent sensorineural hearing loss of some degree of severity and in four this was associated with other neurological problems. The 15 hearing impaired children ranged in age at the time of the illness from 0 (that is illness at birth) to 15 years 3 months; each of the five commonest organisms (excluding 'other bacteria' in table 5) was responsible for at least one case.

Eighteen children developed hydrocephalus as a complication of the meningitis, two of whom died. All but one of the 18 were aged less than 10 months. Four of the 16 survivors suffered a permanent sensorineural hearing impairment (SNHI) making hydrocephalus the most substantial risk factor for SNHI $\left(\chi^{2}=7 \cdot 2, \mathrm{df}=1\right.$, odds ratio $7 \cdot 24,95 \%$ CI $2 \cdot 03$ to $25 \cdot 89$ ). Hydrocephalus was a major contributing factor in the deaths of the three children who died later.

\section{Discussion}

The annual incidence of bacterial meningitis per 100000 in this population of children aged 0-16 years has increased over the decade to 24.0 for 1988-9. This compares with figures of $17 \cdot 8$ for Scotland $^{17}(1971-86$, age $0-13$ years) and $22 \cdot 4$ for Sweden $^{16}$ (1976-80, age 1 month to 16 years). This increasing incidence was not uniform across all ages nor for different infecting organisms. The incidence rate of neonatal meningitis was relatively stable around a level of approximately $25 \cdot 0$, which compares well with Mulder and Zanen's figure of 23.0 for the Netherlands ${ }^{9}$ and Goldacre's 26. 0 in the north west of England. ${ }^{5}$ It is lower than the national rate for England and Wales of $32 \cdot 0$ from the mid- 80 s data reported by de Louvois and colleagues ${ }^{7}$ but that study did not exclude viral causes. The incidence rate in children over 5 years has also remained relatively stable. Most of the increase in incidence was seen in children aged between 1 month and 4 years infected with $N$ meningitidis. The concentration of the increase in this age group has important implications for follow up resources and the provision of specialist services. It is these children who are the most difficult to assess particularly in terms of auditory function yet it is vital that an accurate auditory assessment is made to allow early detection and management of any impairment which could adversely affect the development of speech, language, and cognition. However, when evaluating the data in the 
figure and assessing the impact and resource implications of meningitis, the fact that the age groups differ in size with respect to the number of children in the general population must be considered.

Incidence data are essential to enable assessment of the potential health gain when considering the introduction of preventive measures such as vaccines. From October 1992 a vaccine against $H$ influenzae has been available in the UK to all children at the age of 2 to 4 months. From the data in table 3 we can calculate the implications if the vaccine had been available in the 10 years of the study assuming $100 \%$ coverage and $100 \%$ effectiveness. In Nottingham District Health Authority it might have prevented 78 cases of meningitis, including one death and three cases of permanent sensorineural hearing loss. It might not have prevented six cases of the illness in children aged less than 4 months, two of whom died.

The overall case mortality rate in this series is high at $11 \cdot 6 \%$. This compares with rates ranging from $1 \cdot 8 \%$ to $4 \%$ in other studies. ${ }^{616} 17$ This may be explained by the higher rate in neonates and in the more seriously ill children who were transferred in but excluding these children, overall mortality only drops to $7 \cdot 4 \%$. The trend of increasing mortality for $N$ meningitidis and $H$ influenzae is worthy of further study as it is these organisms that contribute most to the increase in incidence.

Nearly one in 10 of survivors in this study suffered some form of permanent neurological or psychological sequelae but this is likely to be an underestimate as all information on neurological status was gathered retrospectively from hospital casenotes and no follow up of the children was attempted.

The low rate of permanent sensorineural hearing loss in the survivors compared with other studies $^{18}$ may be due in part to differences between studies in the proportions of the various causative organisms. This study finds that sensorineural hearing loss after meningitis in the UK can be caused by many different organisms in children of any age. It is therefore important that all children recovering from bacterial meningitis should be referred for full audiological assessment.

Bacterial meningitis plays an important part in the mortality and morbidity of children in the UK. Although it does not affect a large number of children, it kills or permanently damages at least one fifth of those affected. All possible efforts should be made to control the infection, and data such as those presented here provide much needed background epidemiological information on which to base further work to identify the areas where improvements in therapy or prevention are most needed.

We would like to thank Dr P Ispahani for her considerable effort in supplying the list of laboratory cases, $\mathrm{Dr}$ John DeLouvois for the Karim Centre data, Dr Ken Mason for the cases from official notifications, and Professor Mark Haggard and Professor Sir David Hull for constructive comments on an earlier draft of this paper.

I Sangster G, Murdoch JM, Gray JA. Bacterial meningitis 194079. ₹ Infect 1982; 5: 245-55.

2 Lebel MH, Freij BJ, Syrogiannopoulos GA, et al. Dexamethasone therapy for bacterial memingitis. Results of two 319: $964-71$

3 Girgis NI, Farid Z, Mikhail IA, Farrag I, Sultan Y, Kilpatrick ME. Dexamethasone treatment for bacterial meningitis in children and adults. Pediatr Infect Dis F 1989; 8: 848-51.

4 Odio CM, Faingezicht I, Paris M, et al. The beneficial effects of early dexamethasone administration in infants and children with bacterial meningitis. $N$ Engl f Med 1991; 324: $1525-31$.

5 Goldacre MJ. Acute bacterial meningitis in childhood. Incidence and mortality in a defined population. Lancet 1976; i: 28-31.

6 Dodge PR, Davis H, Feigin RD, et al. Prospective evaluation of hearing impairment as a sequela of acute bacterial of hearing impairment as a sequela of acut
meningitis. $N E$ Engl 7 Med 1984; 311: 869-74.

7 de Louvois J, Blackbourn J, Hurley R, Harvey D. Infantile meningitis in England and Wales: a two year study. Arch Dis Child 1991; 66: 603-7.

8 Spanjaard L, Bol P, De Jong MCJW, Zanen HC. Bacterial meningitis in 366 children in the Netherlands, 1982-1983. Epidemiology and antibiotic therapy. Tijdschr Kindergeneeskd 1986; 54: 1-8.

9 Mulder CJJ, Zanen HC. A study of 280 cases of neonatal meningitis in The Netherlands. F Infect 1984; 9: 177-84

10 Bell AH, Brown D, Halliday HL, McClure G, McReid M. Meningitis in the newborn - a 14-year review. Arch Dis Child 1989; 14: 873-4.

11 Cartwright KAV, Stuart JM, Noah ND. An outbreak of meningococcal disease in Gloucestershire. Lancet 1986; ii: 558-61.

12 Brookhouser PE, Auslander MC. Aided auditory thresholds in children with post-meningitic deafness. Laryngoscope 1989; 99: 800-8.

13 Taylor HG, Mills EL, Ciampi A, et al. The sequelae of Haemophilus influenzae meningitis in school-age children. N Englf Med 1990; 323: 1657-63.

14 Howard AJ, Dunkin KT, Musser JM, Palmer SR. Epidemiology of Haemophilus influenzae type $b$ invasive disease in Wales. BMF 1991; 303: 441-5.

15 Pomeroy SL, Holmes SJ, Dodge PR, Feigin RD. Seizures and other neurological sequelae of bacterial meningitis in childother neurological sequelae of bacteria
ren. Engl F Med 1990; 323: 1651-7.

16 Salwen KM, Vikerfors T, Olcen P. Increased incidence of childhood bacterial meningitis. A 25-year study in a defined population in Sweden. Scand F Infect Dis 1987; 19: 1-11.

17 Carter PE, Barclay SM, Galloway WH, Cole GF. Changes in bacterial meningitis. Arch Dis Child 1990; 65: 495-8.

18 Fortnum H. Hearing impairment after bacterial meningitis: a review. Arch Dis Child 1992; 67: 1128-33.

19 Fortnum H, Hull D. Is hearing assessed after bacterial meningitis? Arch Dis Child 1992; 67: 1111-2.

20 Schlech WF, Ward JI, Band JD, Hightower A, Fraser DW Broome CV. Bacterial meningitis in the United States, 1978 through 1981. FAMA 1985; 253: 1749-54.

$21 \mathrm{Nadol}$ JB. Hearing loss as a sequela of meningitis. Laryngoscope 1978; 88: 739-55.

22 Ozdamer O, Kraus N, Stein L. Auditory brainstem responses in infants recovering from bacterial meningitis. Audiological in infants recovering from bacterial meningitis. A

23 Wenger JD, Hightower AW, Facklam RR, Gaventa S, Broome CV, and the Bacterial Meningitis Study Group. Bacterial meningitis in the United States, 1986: Report of a multistate surveillance study. F Infect Dis 1990; 162: 131623

24 Trollfors B, Claesson BA, Strangert K, Taranger J. Haemophilus influenzae meningitis in Sweden 1981-83. Arch Dis Child 1987; 62: 1220-3.

25 Claesson B, Trollfors B, Jodal U, Rosenhall U. Incidence and prognosis of Haemophilus influenzae meningitis in children in a Swedish region. Pediatr Infect Dis 1984; 3: 35-9.

26 Tudor-Williams G, Frankland J, Isaacs D, et al. Haemophilus influenzae type b disease in the Oxford region. Arch Dis Child 1989; 64: 517-9.

27 Thomson APJ, Hart CA, Sills JA. Meningococcal disease in Liverpool children 1977-1987: Mode of presentation. Pediatric Reviews and Communications 1990; 5: 109-16.

28 Goldacre MJ, Miller DL. Completeness of statutory notification for acute bacterial meningitis. BMF 1976; 2 : 501-3.

29 Harvey IM, Palmer SR, Peters TJ. Meningitis: can we trust the statistics? Health Trends 1989; 21: 73-6.

30 PSTAT user's manual. Princeton: PSTAT, 1990.

31 Payne CD, ed. GLIM system release 3.77 manual. Oxford: NAG, 1987. 